государственных и муниципальных нужд, регламентирован на высоком уровне экономико-правовой техники.

$$
* * *
$$

1. Земельный кодекс Российской Федерации от 25 октября 2001 года № 136-Ф3 (редакция от 11 июня 2021 года).

2. Богомяков И.В. Недостатки механизма изъятия земельных участков для государственных и муниципальных нужд // Российская юстиция, 2006. № 11. С. 12.

3. Земельный кодекс Российской Федерации от 25 октября 2001 года № 136-Ф3 (редакция от 11 июня 2021 года).

4. Авдонина О.Г. Прекращение права собственности на земельный участок: Автореферат диссертации .... кандидата юридических наук: 12.00.03. Томск, 2011. С. 73-90

5. Земельный кодекс Российской Федерации от 25 октября 2001 года № 136-Ф3 (редакция от 11 июня 2021 года).

6. Земельный кодекс Российской Федерации от 25 октября 2001 года № 136-ФЗ (редакция от 11 июня 2021 года)

\title{
Мустиева М.А. \\ Общая характеристика института прекращения права собственности на землю
} ФГБОУ ВО «Чеченский государственный университет» (Россия, Грозный)

doi: $10.18411 / 1 j-07-2021-93$

\section{Аннотация}

В настоящем научном исследовании разъясняется тематика общей характеристики института прекращения права собственности на землю.

В содержательной части научной работы приводятся общие положения института общей характеристики института прекращения права собственности на землю, с раскрытием основополагающих свойств каждого признака регулирования.

В заключительной части научного исследования регламентируется вывод, по которому отображается необходимость разработки новых нормативных правил на законодательном уровне, в целях минимизации правовых коллизий и совершенствования прозрачности действий рассматриваемого института.

Ключевые слова: прекращение, право, собственность, отчуждение, конфискация, земля, земельный участок, судебное решение, правообладатель, виды.

\section{Abstract}

This research study explains the general characteristics of the institution of termination of land ownership.

In the substantive part of the scientific work, the general provisions of the institute of the general characteristics of the institute of termination of ownership of land are given, with the disclosure of the fundamental properties of each sign of regulation.

In the final part of the scientific study, the conclusion is regulated, which reflects the need to develop new regulatory rules at the legislative level, in order to minimize legal conflicts and improve the transparency of the actions of the institution in question.

Keywords: termination, right, property, alienation, confiscation, land, land plot, court decision, copyright holder, types.

Актуальность темы научного исследования заключается в том, что в практике земельного институт права общей характеристики института прекращения права собственности на землю является одним из основополагающих. 
В этой связи структурированное толкование института прекращения права собственности на землю является побудительным мотивом правильного толкования сущности настоящего научного исследования.

В соответствии с теорией гражданского права Российской Федерации прекращение права собственности считается расторжением гражданских правоотношений.

Прекращение гражданских правовых отношений может быть двух видов: условным или окончательным [1].

Окончательное прекращение гражданских правовых отношений определяется при условии, что предмет договора считается исполненным, когда как условное прекращение подразумевает изменение условий договора, не затрагивая основного предмета.

Прекращение права собственности возможно только при наступлении конкретных юридических фактов - действий или событий.

Доктрина гражданского права Российской Федерации выделяет следующие виды оснований прекращения права собственности на землю:

1. Добровольное отчуждение правообладателем своего земельного участка.

2. Прекращение правовых отношений по владению, распоряжению и пользованию земельным участком лица, в силу наступления юридических действий и событий, не совершившего незаконных действий, в общественных интересах.

3. Принудительное изъятие земельного участка за совершенное собственником правонарушение [2].

Практика гражданского правового оборота регламентирует, что цивилизованным считается механизм добровольного отчуждения правообладателем своего земельного участка, нежели принудительного изъятия земельного участка за совершенное собственником правонарушение.

Добровольное отчуждение правообладателем своего земельного участка возможно посредством гражданско-правовых договоров (купля-продажа, дарения, мена, рента, наследование и иные).

Кроме того, в соответствии с изменениями, произошедшими в статье 53 Земельного кодекса Российской Федерации, к добровольному изъятию земельного участка относится также и отказ от недвижимого имущества, письменно подаваемый в орган регистрации прав на недвижимое имущество [3].

Прекращение правовых отношений по владению, распоряжению и пользованию земельным участком лица, в силу наступления юридических действий и событий, не совершившего никаких незаконных действий, в общественных интересах, определяется, как прекращение правомочия собственности вследствие гибели земельного участка в результате оползня, землетрясения, обвала, а также физического уничтожения.

К принудительному изъятию земельного участка гражданское право Российской Федерации относит:

1. Обращение юридических лиц на взыскание земельного участка, в силу невыполнения договорных обязательств.

2. Отчуждение земельного участка от недобросовестного правообладателя в пользу добросовестного.

3. Реквизиция земельного участка органами государственной власти и органами местного самоуправления.

4. Конфискация земельного участка.

5. В случае невозможности разделения общей долевой собственности.

6. В силу судебного решения. 
7. В случае выкупа земельного участка для государственных и муниципальных нужд [4].

Вместе с тем, в нормативном правовом пространстве Российской Федерации до сих пор нет регламентированной структуризации института классификаций прекращения права собственности на землю.

Объясняется данная коллизия тем, что Российской Федерации относительно недавно стала на рыночный путь становления права собственности.

В этой связи отображается необходимость разработки новых нормативных правил на законодательном уровне, в целях минимизации правовых коллизий и совершенствования прозрачности действий рассматриваемого института.

1. Бутаева Э.С. Прекращение права собственности помимо воли собственника: диссертация ... кандидата юридических наук: 12.00.03. Краснодар, 2008. С. 70.

2. Богомяков И.В. Недостатки механизма изъятия земельных участков // Российская юстиция, 2006. № 11 . С. 12 .

3. Земельный кодекс Российской Федерации от 25 октября 2001 года № 136-Ф3 (редакция от 11 июня 2021 года).

4. Авдонина О.Г. Прекращение права собственности на земельный участок: Автореферат диссертации ... кандидата юридических наук: 12.00.03. Томск, 2011. С. 73-90

\section{Никитина Е.А., Фирсов Г.В. \\ К вопросу об отдельных методах определения последовательности выполнения реквизитов документов}

Волгоградская академия МВД России (Россия, Волгоград)

doi: $10.18411 / \mathrm{j}-07-2021-94$

\section{Аннотация}

Определение последовательности выполнения пересекающихся штрихов может способствовать установлению факта изменения содержания текста в документе путем дописки (дорисовки), а также выявлению относительной последовательности нанесения отдельных реквизитов в документе. Задача, связанная с установлением хронологической последовательности выполнения пересекающихся штрихов, относится к числу одной самых трудных, а иногда неразрешимых и часто требует от эксперта применения комплекса рекомендуемых методов.

Ключевые слова: технико-криминалистическая экспертиза документов, методы исследования, последовательность выполнения реквизитов документов, пересекающиеся штрихи.

\section{Abstract}

Determining the sequence of intersecting strokes can help to establish the fact of changing the content of the text in the document by adding (finishing), as well as identifying the relative sequence of applying individual details in the document. The task associated with establishing a chronological sequence of intersecting strokes is one of the most difficult, and sometimes unsolvable, and often requires an expert to apply a set of recommended methods.

Keywords: technical and forensic examination of documents, research methods, sequence of execution of document details, intersecting strokes.

При расследовании определенных категорий преступлений возникает необходимость в технико-криминалистическом исследовании документов, представляющих важное значение для квалификации произошедшего события. Речь идет о 